\title{
XI. An Air-mercury pump, for raising mercury in different kinds of mercurial pumps
}

\section{Frederick J. Smith M.A.}

To cite this article: Frederick J. Smith M.A. (1892) XI. An Air-mercury pump, for raising mercury in different kinds of mercurial pumps, Philosophical Magazine Series 5, 34:206, 115-117, DOI: $10.1080 / 14786449208620170$

To link to this article: http://dx.doi.org/10.1080/14786449208620170

曲 Published online: 08 May 2009.

Submit your article to this journal $\lceil\pi$

Џ Article views: 2

Q View related articles $\asymp$ 
XI. An dir-mercury Pump, for raising Meroury in different kinds of Mercurial Pumps. By Frederick J. Sмгтн, M.A., Millard Lecturer on Mechanics and Physies, Trinity College, Oxford*.

MANY people who constantly use the mercury-pump of 1 Sprengel, or other forms of pumps in which a vacuum is produced by the fall of mercury, must have folt that it would be a considerable help in their work if the mercury which falls in working the pump could be returned at once to the cistern at the top of the instrument without any personal attention, so that the process of exhaustion might go on without interruption for days together if nece sary. The instrument which I now describe, when added to the ordinary mercurial pump, renders it perfectly self-acting. I propose to call the device the Mercury Elevator.

In the Philosophical Magazine for 1888, vol. xxv. p. 313, I described a water-engine, whereby mercury was raised for driving a pump used for exhausting glow-lamps. This arrangement was satisfactory but costly, and required careful adjustment. The instrument about to be described produces the same results, while it can be easily made up from apparatus in daily use in every laboratory. The idea of a Sprengel pump completely reversed both in position and action, first suggested to me the possibility of making this instrument.

The mercury elevator is nothing more than a Sprengel pump, inverted, and worked backwards. Where a vacuum is formed under ordinary circumstances, air is forced in, and instead of little cylinders of mercury falling they are raised.

The construction is shown in the appended diagram, where $A$ is the cistern of the Sprengel or other mercurial pump ; BC D, a tube furnished with a side tube at C, and attached at $D$ to the catcher of the Sprengel pump E. By means of the pinch-cock $F$, the supply of compressed air is controlled. The air may be compressed either by an ordinary condensing pump driven by any prime mover, or by the following arrangement, which may be used where there is a supply of water at a sufficient pressure.

$G$ is an ordinary water-pump. When water under pressure enters at $L$, air is drawn in at $G$, and is discharged at $\mathrm{K}$ into a copper cylinder $\mathrm{H}$; here the air and water separate;

* Communicated by the Author.

I 2 
the air passes through the tube $P$ to a drying-chamber $Q$, and to the elevator $\mathbf{R ~} \mathrm{C} \mathrm{B}$, the water rises in the tube $\mathrm{M} \mathrm{N}$, and is discharged at $\mathrm{N}$ (the tubes are shown broken to economize space in the diagram); the pressure of the air is controlled by the pressure of the supply at $L$, and by the vertical height of $\mathrm{MN}$.

When the elevator is to be used, water is turned on at $L$, till it flow's freely at $N$, and $F$ is slightly opened; then the Sprengel pump is started. As soon as sufficient mercury

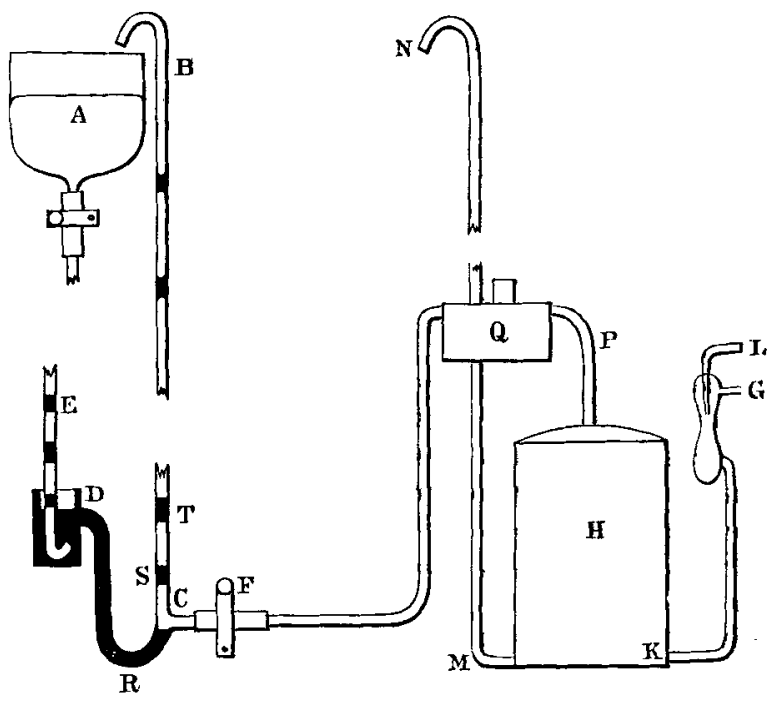

has collected to overflow, it is immediately raised by the compressed air into $\mathrm{A}$, the sum of the lengths of the little columns such as $\mathrm{S}, \mathrm{T}$, \&c. being less than the length of the column R D.

As the water used in compressing the air is in no way injured by the process, it may fill a tank and be used for any purpose.

The elevator will of course raise many other liquids besides mercury. If water is used instead of air, the mercury is also raised but wetted in the process. Water may be used when fluids which do not mix with it are to be dealt with.

In the diagram the supports which carry the tubes, \&c., have been left out for the sake of clearness. In the instrument, which has been at work for the last two years in the Millard Laboratory, the height of the tube MN is about eight feet, and the pressure of water at $\mathrm{L} 36 \mathrm{lb}$. per square 
inch. After the elevator has been started the supply of water may be reduced till just sufficient to raise the mercury. The quantity of water then used to keep it going is very small. I may add, in conclusion, that the air-compressor is also used in the laboratory for supplying a blowpipe and small gas-furnace, and other lecture-apparatus in which compressed air is required.

Oxford, June 11, 1892.

XII. The Action of Dried Hydrochloric-Acid Gas on Teeland Spar. By R. E. HUGHws, B.Sc., Scholar of Jesus College, Oxford, and F. R. L. Wilson, B.A., Scholar of Keble College, Oxford*.

K OHLRAUSCH asserts that all pure substances are electrolytes, and if the assumption of Ostwald be true that chemical reactions take place only between the electrolytic ions, it follows that no reactions are possible between pure substances, and only become possible in the presence of some body which is sapable of producing the electrolytic dissociation.

Inasmuch as the majority of chemical reactions take place in the presence of water or some other solvent, and since the experiments of Dixon on the explosion of mixtures of dried gases, Wanklyn on the action of dry chlorine on metals, Baker on the combustion of dry substances, and Veley on the action of dry sulphuretted hydrogen on oxide of calcium, prove that the presence of water is an essential condition for these reactions to take place, it seemed an interesting question to determine whether dried hydrochloric-acid gas is capable of displacing carbon dioxide from carbonates.

Therefore, at the suggestion of Mr. V. H. Veley, M.A., we have undertaken an investigation with this object in view.

It must be mentioned that the action of liquefied hydrochloric acid on various carbonates has been investigated by Gore, as a result of which he found that, with the exception of calcium carbonate, all the carbonates investigated showed a more or less complete conversion into the chlorides.

Wiedemann, in the British Association Report for 1887, states that "Dr. Gore has shown that if you put anhydrous liquefied hydrochloric acid upon carbonate of lime, the carbonic acid is chased away and calcinm chloride is formed"; but what evidence there is for such a statement we are at a loss to determine.

$$
\text { * Communicated by Professor Odling, F.R.S. }
$$

